\title{
References
}

Hjort, C. 1973: A sea correction for East Greenland. Geol. Fören. Stockh. Förh. 95, 132-134.

Tauber, H. \& Funder, S. 1975: $\mathbf{C}^{14}$ content of recent molluscs from Scoresby Sund, central East Greenland. Rapp. Grønlands geol. Unders. 75, 95-99.

Geologisk Museum,

Oster Voldgade 5-7,

$D K-1350$ Copenhagen $K$.

\section{The Kap Leiper basic dyke and the age of the dolerites of Inglefield Land, North-West Greenland}

\author{
Peter R. Dawes, John S. Peel and David C. Rex
}

This note reports field observations (PRD and JSP) and K/Ar whole-rock dating work (DCR) on dolerite intrusions from south-western Inglefield Land. The stratigraphic relationships of the intrusions and the significance of the $\mathrm{K} / \mathrm{Ar}$ ages are briefly discussed.

\section{General geology}

The Precambrian crystalline basement of North-West Greenland is unconformably overlain by unmetamorphosed and undeformed Proterozoic sediments, with some volcanics, of the Thule Group. This sequence reaches a thickness of several kilometres in the Thule Basin. In Inglefield Land, to the north, the Proterozoic sequence (Rensselaer Bay Formation) is about $200 \mathrm{~m}$ thick and thins out completely in the region of Marshall Bugt (fig. 3).

The Thule Group is characterised by appreciable amounts of dolerite material in the form of sills and dykes that form a widespread igneous province from $76^{\circ} \mathrm{N}$ to the Rensselaer Bugt area of Inglefield Land at about $78^{\circ} 30^{\prime} \mathrm{N}$. The $\mathrm{K} / \mathrm{Ar}$ ages reported on here are from the northernmost dolerite outcrops of the Proterozoic igneous province.

\section{Field relations}

Three samples are treated in the present study; one is.from a dyke at Kap Leiper, the others are from a pair of prominent stills that occur throughout much of south-western Inglefield Land. Both the dyke and the sills were mentioned by Koch (1933) who also noted that the Kap Leiper dyke represents the most northern dolerite intrusion in North-West Greenland.

The Kap Leiper dyke is only exposed on the coast at the cliff foot. It is about $35 \mathrm{~m}$ thick with a vertical outcrop of about $30 \mathrm{~m}$ (fig. 4). The dyke forms a small coastal promontory and from its trend and the rather poorly exposed contacts it appears to strike approximately 


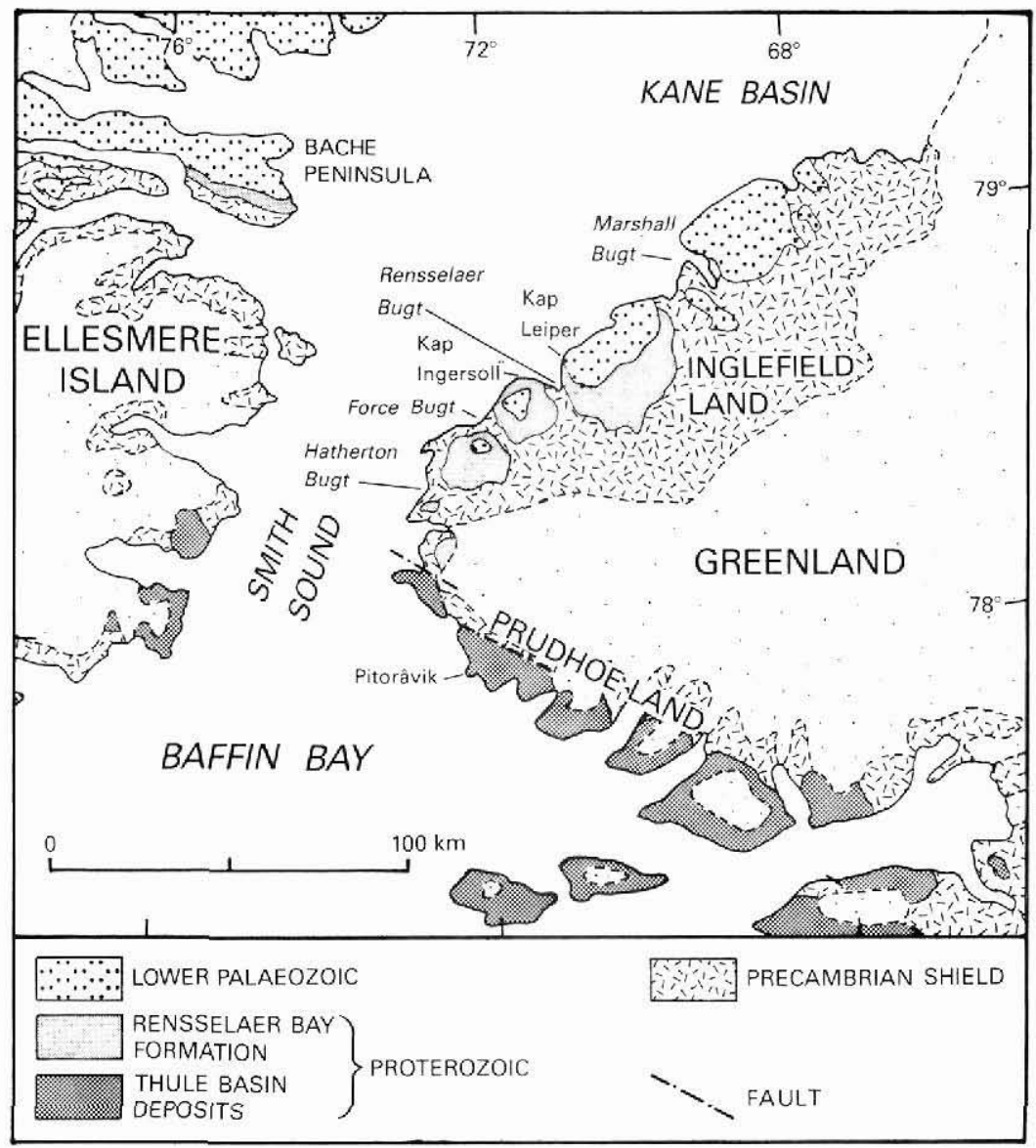

Fig. 3. Generalised geological and index map of the Inglefield Land - Prudhoe Land area of North-West Greenland and adjacent Ellesmere Island.

WNW. The dyke cuts sandstones and siltstones of the Proterozoic Rensselaer Bay Formation, but its relationship to the overlying Dallas Bugt Formation of Cambrian age is obscured by talus (fig. 4). However, the dyke does not penetrate the overlying cliff-forming dolomites of the Cape Leiper and Cape Ingersoll Formations of Troelsen (1950), or succeeding Lower Cambrian limestones.

The age and field relationships of the Kap Leiper dyke have received much comment in the literature. Koch (1933, p. 21) noted that the dyke did not penetrate the entire cliff succession, but he assumed that it post-dated the dolomites, as indicated on his geological map (Koch, 1933, pl. II). Christie (1967, p. 55), on the basis of stratigraphic relationships at Bache Peninsula, Ellesmere Island (fig. 3), suggested that the portrayal of dolerite cutting dolomite in Koch's map "could easily be an error" and our observations indicate that this is the case. 


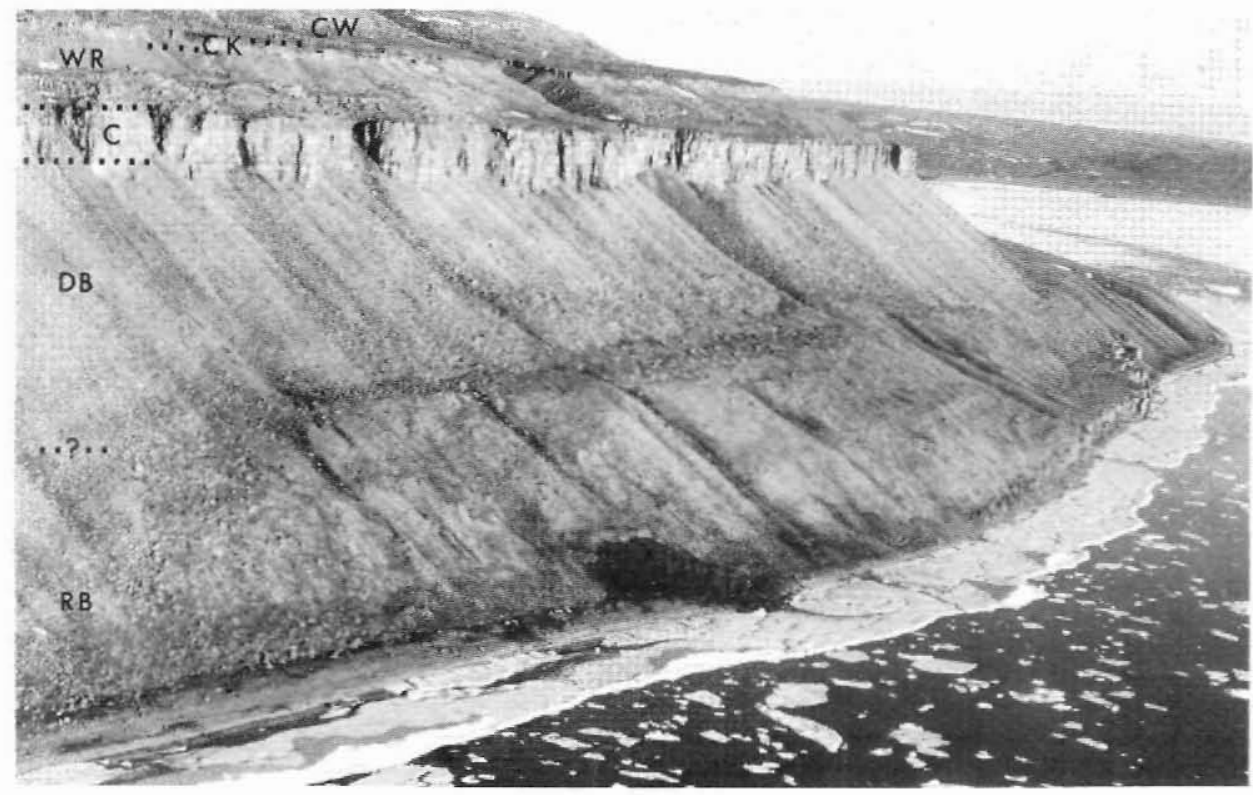

Fig. 4. The Kap Leiper dyke on the shore-line just north-east of Kap Leiper, viewed from the north with Rensselaer Bugt beyond. Sandstones of the Rensselaer Bay Formation (RB), cut by the dyke, are exposed adjacent to the intrusion and along the shore toward Kap Leiper. The overlying Dallas Bugt Formation (DB) is largely talus covered, but its uppermost beds outcrop at the foot of the cliff formed by the dolomites of Cape Leiper and Cape Ingersoll Formations (C). Overlying Lower to Middle Cambrian limestones are referred to the Wulff River (WR), Cape Kent (CK) and Cape Wood (CW) Formations.

Similar discussion has also surrounded the stratigraphic age of the two sills since they were described and figured by Koch (1933, fig. 13, pl. II) (see for example Cowie, 1961, p. 21). On the east side of Force Bugt, where the samples used in our study were collected, the lower sill is at least $25 \mathrm{~m}$ thick, and the upper sill is about $20 \mathrm{~m}$ thick. Our field data show that the sills occur within the Rensselaer Bay Formation and that the upper sill in places occurs immediately below the unconformity with the Dallas Bugt Formation. In detail, the upper sill has an irregular, rubbly, eroded upper surface and, in some places, for example at Force Bugt, it is cut out by the overlying Cambrian beds.

\section{The material}

The Kap Leiper dyke and the two sills are composed of grey to brownish weathering, ophitic to sub-ophitic dolerite with fine-grained, chilled margins. In thin section the material is seen to be slightly to moderately altered with uralitisation of the clinopyroxene and saussuritisation of the plagioclase. The freshest dolerite is sample GGU 242169 from the lower sill at Force Bugt; the most altered material is sample GGU 242171 from the upper 
Table 1. K/Ar whole rock ages and details of dolerite samples from North-West Greenland

\begin{tabular}{|c|c|c|c|c|c|c|}
\hline $\begin{array}{l}\text { GGU } \\
\text { sample } \\
\text { no. }\end{array}$ & $\begin{array}{c}\text { Rock type } \\
\text { geological setting }\end{array}$ & $\begin{array}{l}\text { Intrusive } \\
\text { field relations }\end{array}$ & $\% \mathrm{~K}$ & $\begin{array}{l}\text { Vol. }{ }^{40} \mathrm{Ar} \\
\text { rad. } \mathrm{scc} / \mathrm{g} \\
\times 10^{-4}\end{array}$ & $\begin{array}{l}{ }^{\%}{ }^{40} \mathrm{Ar} \\
\text { rad. }\end{array}$ & Age m.y. \\
\hline 242160 & Dyke at Kap Leiper & $\begin{array}{l}\text { Post-Rensselaer Bay } \\
\text { Formation }\end{array}$ & 0.755 & 0.2200 & 93.1 & $627 \pm 25$ \\
\hline 242171 & $\begin{array}{l}\text { Upper of two sills } \\
\text { Force Bugt }\end{array}$ & $\begin{array}{l}\text { Post-Rensselaer Bay } \\
\text { Formation }\end{array}$ & 1.531 & 0.8815 & 96.7 & $1081 \pm 40$ \\
\hline 242169 & $\begin{array}{c}\text { Lower of two sills } \\
\text { Force Bugt }\end{array}$ & $\begin{array}{l}\text { Post-Rensselaer Bay } \\
\text { Formation }\end{array}$ & 1.913 & 1.1366 & 94.7 & $1107 \pm 40$ \\
\hline $140802 *$ & $\begin{array}{l}\text { ESE-trending dyke at } \\
\text { Pitorâvik, Prudhoe Land }\end{array}$ & $\begin{array}{l}\text { Post-Upper } \\
\text { Thule Group }\end{array}$ & 0.77 & 0.2497 & 90.8 & $676 \pm 25$ \\
\hline $140856^{*}$ & $\begin{array}{l}\text { Lower of two sills } \\
\text { Hatherton Bugt } \\
\text { sW Inglefield Land }\end{array}$ & $\begin{array}{l}\text { Post-Rensselaer Bay } \\
\text { Formation }\end{array}$ & 2.00 & 1.1536 & 99.1 & $1073 \pm 40$ \\
\hline
\end{tabular}

$\lambda_{\beta}=4.72 \times 10^{-10} \mathrm{yr}^{-1} \quad \lambda_{\mathrm{e}}=0.584 \times 10^{-10} \mathrm{yr}^{-1}$

${ }^{40} \mathrm{~K} / \mathrm{K}=1.19 \times 10^{-4} \mathrm{~mole} / \mathrm{mole} \mathrm{K} \quad$ *Samples from Dawes et al. (1973).

sill at the same locality. The petrography of the Kap Leiper dyke has been described by Callisen (1929) who referred to the rock as a quartz diabase.

The samples used in the present study are all fine grained and collected from near the margins of the intrusions.

\section{Experimental procedure}

The K/Ar analyses were carried out by DCR in the geological laboratories of the University of Leeds. The samples were crushed and sieved and the 60-90 mesh fraction was selected. Argon was extracted 'in vacuo' and measured by isotope dilution on an AEI MS10 mass spectrometer, following the method described by Rex \& Dobson (1970). Potassium was determined by flame photometry in triplicate, the figure given here being the average of the three measurements (Table 1).

\section{The $K /$ Ar ages}

The K/Ar ages obtained on the three samples are given in Table 1. Owing to the altered nature of the analysed dolerite and the possibility of argon loss, the dates are regarded as minimum ages of intrusion and they are accepted as inferring minimum ages for the rock strata which they cut.

The date of $627 \pm 25 \mathrm{~m} . \mathrm{y}$. on the Kap Leiper dyke indicates that it pre-dates the Dallas Bugt Formation which, on the basis of trace fossils and its apparent conformity below Lower Cambrian carbonates, is considered to be of Early Cambrian age (Peel et al., 1982). The dates of $1081 \pm 40$ m.y. and $1107 \pm 40$ m.y. for the two sills suggest that the Rensselaer Bay Formation is of middle Proterozoic (Helikian) age. 
These results compare favourably with those obtained on dolerite farther south in North-West Greenland (Dawes et al., 1973). The only other K/Ar age on dolerite from Inglefield Land is $1073 \pm 40$ m.y. on a sill at Hatherton Bugt in the extreme south-west, while the nearest dated basic dyke, at Pitorâvik in coastal Prudhoe Land, has given a K/Ar age of $675 \pm 25$ m.y. (Table 1; fig. 3).

\section{Magmatic episodes}

From field evidence, including that of cross-cutting relationships from the Thule Basin region, south of Inglefield Land, it appears that this area of North-West Greenland was subjected to at least two episodes of Proterozoic basic magmatism. An earlier episode is represented by extrusives and associated sills, while the later episode contains only intrusives in the form of both dykes and sills. In some areas, basic sills are seen to have been faulted prior to dyke intrusion. Dykes of the later period cut the youngest strata of the Thule Group, the Narssârssuk Formation, which on microfossil evidence is considered to be Vendian in age (Vidal \& Dawes, 1980). Both episodes of magmatism are widely represented within the outcrop area of the Thule Basin.

Previous isotopic analysis of dolerites from this area south of Inglefield Land has established that the oldest of the two magmatic episodes is of Helikian age, with a K/Ar age range of $1190 \pm 40$ to $1070 \pm 40$ m.y. This older magmatic episode may well correlate with igneous activity that has given Rb-Sr whole-rock ages of $c .1250$ m.y. in eastern North Greenland (Jepsen \& Kalsbeek, 1979) but from which K/Ar dates of 799 \pm 68 m.y. and 982 \pm 19 m.y. have been obtained (Henriksen \& Jepsen, 1970). The younger episode is Hadrynian, with a $\mathrm{K} / \mathrm{Ar}$ age range of $764 \pm 30$ to $532 \pm 20 \mathrm{~m}$.y. (Dawes et al., 1973). The three K/Ar ages reported in this paper indicate that the two magmatic episodes present in the Thule Basin can also be recognised as far north as the Rensselaer Bugt area of Inglefield Land. Hence, an earlier speculation that the Kap Leiper dyke may represent an offshoot of a Helikian sill (Dawes et al., 1973, fig. 8) is abandoned.

The Thule Basin is a middle to late Proterozoic intracratonic basin developed on the northern margin of the North American craton. Tensional faulting has played an important role in its development and a major intrusion phase of the Hadrynian magmatic period is a regional swarm of WNW-trending dykes which parallels a prominent fault direction in the basin.

The field character and the K/Ar age of the Kap Leiper dyke suggest that it is a member of this regional dyke swarm. Unmetamorphosed dolerite intrusions have not been reported north of Kap Leiper, neither within the Rensselaer Bay Formation, that thins out rapidly to the north, nor within the Precambrian Shield. The northernmost basic intrusion of the Helikian episode is the sill on the western side of Rensselaer Bugt; this is the same intrusion as the upper sill at Force Bugt dated in this report. It is particularly noteworthy that the northern termination of both the Helikian and the Hadrynian magmatic episodes occurs in the same area, around Rensselaer Bugt, suggesting that both periods of Proterozoic magmatism were closely connected with the development of the intracratonic Thule Basin. 


\section{References}

Callisen, K. 1929: Petrographische Untersuchung einiger Gesteine von Nordgrönland. Meddr Grønland 71 (6), 217-255.

Christie, R. L. 1967: Bache Peninsula, Ellesmere Island, Arctic Archipelago. Mem. geol. Surv. Can. 347, 63 pp.

Cowie, J. W. 1961: Contributions to the geology of North Greenland. Meddr Grønland 164 (3), $47 \mathrm{pp}$.

Dawes, P. R., Rex, D. C. \& Jepsen, H. P. 1973: K/Ar whole rock ages of dolerites from the Thule District, western North Greenland. Rapp. Grønlands geol. Unders. 55, 61-66.

Henriksen, N. \& Jepsen, H. F. 1970: K/Ar age determinations on dolerites from southern Peary Land, North Greenland. Rapp. Gronlands geol. Unders. 28, 55-58.

Jepsen, H. F. \& Kalsbeek, F. 1979: Igneous rocks in the Proterozoic platform of eastern North Greenland. Rapp. Grønlands geol. Unders. 88, 11-14.

Koch, L. 1933: The geology of Inglefield Land. Meddr Gronland 73 (1), 2, 38 pp.

Peel, J. S., Dawes, P. R., Collinson, J. D. \& Christie, R. L. 1982: Proterozoic - basal Cambrian stratigraphy across Nares Strait: correlation between Inglefield Land and Bache Peninsula. In Dawes, P. R. \& Kerr, J. W. (edit.) Nares Strait and the drift of Greenland: a conflict in plate tectonics. Meddr Grønland, Geoscience 8.

Rex, D. C. \& Dobson, M. H. 1970: Improved resolution and precision of argon analyses using an AEI MS10 mass spectrometer. Eclog. geol. Helv. 63, 275-280.

Troelsen, J. C. 1950: Contributions to the geology of Northwest Greenland, Ellesmere Island and Axel Heiberg Island. Meddr Grønland 149 (7), 86 pp.

Vidal, G. \& Dawes, P. R. 1980: Arcritarchs from the Proterozoic Thule Group, North-West Greenland. Rapp. Grønlands geol. Unders. 100, 24-29.

D. C. R., Department of Earth Sciences, University of Leeds, Leeds LS2 9JT,

U.K.

\section{Towards a refined stratigraphy for the basalts of Svartenhuk Halvø}

\section{Karl A. Jørgensen}

Mapping of the Tertiary basalts of the Svartenhuk Halvø area (Larsen, 1981a,b) at a scale of 1:100000 (sheet $71 \mathrm{~V} \mathrm{~N}$ ) was continued during the 1981 field season (fig. 5). The work was concentrated on the northern and north-western part of the area, with emphasis on detailed profiles rather than on general mapping. A total of 11 profiles were measured, with an aggregate thickness of $6000 \mathrm{~m}$. The profiles are divided into two including (a) four main profiles which were intensely sampled and (b) seven auxilliary profiles, which have only been moderately sampled. The measured profiles give an overlapping view of the middle formation of Larsen (1981), while the lower and upper formations have only been partially measured and sampled (fig. 5). 